\title{
New Zealand Report
}

\section{Drinking and smoking in the land of the long white cloud}

\author{
RICHARD SMITH
}

Turning my back on two long chains of purple mountains, the Richmond and Arthur ranges, and walking out of the sun, the brightest in the world, into a dark, cold bar in Motueka, New Zealand, I was reminded immediately of a bar in the Maryhill Road, Glasgow. Three short, toothless, drunk men, who looked 50 but were probably 35, and who may have been working but were more likely unemployed, sat at a table covered in empty bottles and full ashtrays, pointing fingers at each other and discussing the state of Kiwi rugby. Outside might have been scenery that has travel agents reaching for the thesaurus but inside it was just like an inner-Glaswegian scene of excessive drinking, heavy smoking, and premature aging.

New Zealand, "Godzone" as the Australians like to sarcastically call it, has alcohol and smoking problems that rank alongside those of Scotland, a country notorious for such problems. About 4000 New Zealanders a year die because of their smoking (the population is just over $3 \mathrm{~m}$ ), and Maori women have one of the highest incidences of lung cancer in the world. ${ }^{1}$ (Despite this the New Zealand government is helping build a cigarette factory in Samoa.) New Zealanders drink a little more alcohol than the Scottish and have just as many alcohol-associated problems. I worked for a year in New Zealand in 1978 after having worked in Scotland: alcoholic cardiomyopathy, liver failure from alcoholic cirrhosis, and other physical complications of alcohol abuse all seemed much commoner in New Zealand than Scotland. The tuberculosis unit in which I worked contained almost exclusively Pacific Islanders, Maoris, and pakeha (European) alcoholics, and the piano would not play in tune because it was full of empty bottles. Less subjective studies confirm that New Zealand has formidable alcohol-related problems, ${ }^{12}$ and alcohol seems to account for a higher percentage of road traffic accidents than in any other country in the world (W A Parkins in a paper presented to the Australia and New Zealand Association for the Advancement of Science conference, in Auckland, 1979).

What is different between Scotland and New Zealand, however, is that New Zealand has been slow to take initiatives to deal with smoking and alcohol problems. This is surprising as New Zealand is not slow in most medical and social matters: it has had a free health service for as long as Britain; spends a higher percentage of its gross national product on health care; is a world leader in various medical specialties-for example, cardiothoracic surgery; and has pioneered important social welfare schemes-for example, no-fault accident compensation. Yet the Australasian Royal Medical Colleges have never produced reports on the danger of smoking and drinking; there is no equivalent of the Health Education Council or the Scottish Health Education Group; belated attempts to found a New

British Medical Journal, London WC1H 9JR RICHARD SMITH, BSC, MB, assistant editor
Zealand equivalent of the British Action on Smoking and Health (ASH) have met difficulties; and although there is a statutory body for dealing with alcohol problems-the Alcoholic Liquor Advisory Council (ALAC)-its organisation makes it difficult for it to be effective.

Although they have agreed that shifting health resources towards preventive measures is important, most developed countries have been slow to do so. But why should New Zealand, with its considerable problems, be even slower than most ? Is it because a country where the pioneers are not long in their graves is unenthusiastic about measures that "interfere with a man's freedom to drink and smoke ?" (Unlikely, as wearing seat belts has long been a legal requirement.) Is it because the medical profession is that bit more conservative in New Zealand and has been slow to take a lead? Is it just because everything happens more slowly in New Zealand? (Although various people suggested this almost facetiously as a reason, in fact many innovations happen faster in New Zealand than Britainfor example, the introduction of a no-fault accident compensation system.) Or is it just the long reign of right-wing politicians?

When I was in New Zealand recently I spent some time looking at smoking and drinking problems in New Zealand and what is and what is not being done about them.

\section{Turning away from smoking}

Despite the absence of any very active antismoking campaign or any active pressure group, New Zealanders smoke less than the British and were smoking less in 1981 than they were in $1976 .^{3} 4$ The 1976 New Zealand Census included questions about smoking and was the first large-scale survey of smoking habits: it showed that $38 \%$ of men and $32 \%$ of women smoked compared with $46 \%$ of men and $38 \%$ of women in Britain. ${ }^{5}$ At that time $16 \%$ of the population said that they had given up cigarette smoking. Although no social class breakdown was given it was known that New Zealand doctors were stopping smoking, ${ }^{6}$ and as in other countries those who had tried to give up were probably in the higher social classes.

A preliminary analysis of the result of the 1981 census showed that $35 \%$ of men and $29 \%$ of women smoked. ${ }^{4}$ The fall between the two periods was seen in all groups except among women under 24 , and, indeed, women under 24 smoked more than men under 24. The good news of falling smoking rates has been supplemented by data showing that coronary heart disease mortality has also been falling in New Zealand.

So with things improving at a rather faster rate than in Britain, where there is a lot of antismoking lobbying, does New Zealand really need an antismoking lobby group? Dr Robert Beaglehole from the department of community health in Auckland Medical School thinks that it definitely does. A lobby group could make tobacco consumption fall faster, ensure that the decline is not halted, and concentrate on those age, social, and cultural groups where there is no fall. 
Accordingly, a few New Zealanders have been trying to create an antismoking group. They intend to call the organisation ASH (NZ) Inc and have agreed that name with the British ASH. The idea surfaced in New Zealand in April 1980 at a health education workshop. The British ASH was founded in 1971, eight years after the Royal College of Physicians first report on smoking, and the slowness of the New Zealanders deserves some examination. The first idea of the New Zealanders was that they should develop an antismoking policy. But what would they do with such a policy? The government was not enthusiastic, and there was no other organisation to take it on board. Thus they arrived at the idea of a lobby group modelled on the British ASH.

The next step was to find money. Although the British ASH is mainly financed by the Government, the New Zealand Government were unwilling to provide any money and nor could the medical colleges. The National Heart Foundation and the Cancer Society did, however, give $\$ 5000$ each and the Asthma Society gave $\$ 3000$-very small amounts when compared with that spent on tobacco advertising. Such limited resources allowed only a part-time director. An energetic and innovative director is the sine qua non of a good pressure group, and finding such a person may be very difficult in a small country.

Just before I left a good example was provided of why such an organisation is necessary in New Zealand. A 1927 Police Offences Act was replaced, which was reasonable as most of the Act was outdated. But one clause of the Act covered young people buying cigarettes, and it is now legal in New Zealand for children of any age to buy cigarettes and school tuck shops could now contain cigarette machines. The Government's advisory committee on smoking and health had pointed out this anomaly, but the Government refused to do anything. A New Zealand ASH could make great play of such neglect.

\section{Ineffectual action on alcohol}

Alcohol abuse is a bigger issue than smoking problems, and New Zealand has a long history of concern over alcohol problems. ${ }^{2}$ Between 1893 and 1918 there was an intense temperance campaign, and since 1893 New Zealanders have voted every three years (at the same time as general elections) on three options for an alcohol policy-prohibition, State control, or a continuance of the status quo. In $1919,48.6 \%$ of the electorate voted for prohibition, and this failed by only 3263 votes. In $198122 \%$ voted for prohibition, but the vote has become somewhat meaningless as no information is provided on the implications of the three options.

Despite this concern over alcohol problems, since 1960 licensing laws have become much more liberal, the real price of alcohol has dropped, and per caput consumption has increased by $59 \%$ from 5.371 of absolute alcohol per head in 1961 to 8.641 in 1980 (latest figures supplied by ALAC). ${ }^{2}$ Consumption per head in England and Wales in 1979 was 8.39 1 of pure ethanol. Beer has always been the main New Zealand drink, but it is the consumption of wine that has increased most dramatically -by about fivefold between 1961 and 1979. In large part this reflects the growth of the New Zealand wine industry: in 1960 there were 388 hectares of vineyards, but in 1979 there were 4177. ${ }^{2}$ In 1960 New Zealand wine was a huge joke, but now it raises only a small titter: some of it is very good.

The ambivalence of the New Zealand Government over alcohol problems is well illustrated by its involvement with the wine industry. Twenty-three politicians attended the Wine Institute's dinner and the Prime Minister, Robert Muldoon, proposed a toast, whereas only two politicians said they would attend a Royal Society meeting to discuss alcohol problems and so the meeting was cancelled. ${ }^{8}$ Then, New Zealand white wine is taxed at 3.5 cents per $1 \mathrm{ml}$ of absolute alcohol, whereas New Zealand beer is taxed at 11.7 cents and New Zealand whisky at 16.5 cents. $^{8}$ Wine is pushed by the industry as the "drink of moderation," and the myth that you will be less damaged by alcohol drunk as wine rather than as spirits or beer seems to have taken root in New Zealand-so much so that New Zealand brewers are very worried and are now trying to push beer as the true drink of moderation. This unseemly battle over moderation is not helped by literature produced by ALAC that suggests that you may need to drink $2 \frac{1}{3}$ bottles of light wine, $6 \frac{2}{3}$ bottles of beer, or $2 / 3$ bottle of spirits (sic) before you reach drunkenness. ${ }^{9}$

The Government is enthusiastic about wine because it believes that eventually it will become a profitable export: the industry plans to double its output to $80 \mathrm{~m}$ litres by the $1990 \mathrm{~s} .{ }^{8}$ But in a world awash with European, Californian, South American, and Australian wine and with the main markets on the other side of the world, who is going to buy New Zealand wine? Nobody, believe most of the people concerned about alcohol problems. They think that much of those extra $40 \mathrm{~m}$ litres will be drunk by New Zealanders.

Just as in Britain and many other countries, the Government receives much of its revenue from tax on alcohol, and some 37000 people (3\% of the workforce) are employed in the alcohol trade. ${ }^{2}$ In such circumstances neither the Government nor any politicians are too keen on political initiatives to limit alcohol consumption.

As in every other country in the world, ${ }^{10}$ as alcohol consumption has risen in New Zealand so has associated damage. The death rate from alcohol-related causes rose by $75 \%$ between 1970 and 1978, and deaths from cirrhosis trebled between 1948 and 1978. ${ }^{2}$ Particular problems in New Zealand, an empty but affluent country with poor public transport and a long coastline, are traffic accidents and drowning. In 1977 about 350 deaths and nearly 9000 injuries on the roads were estimated to be related to alcohol, ${ }^{2}$ and about half of the 126 drownings of those over 15 in 1970 may have resulted from excessive drinking. Drunken driving is a particularly contentious issue in New Zealand, where Christmas and midsummer coincide, but neither random breathalysing nor a lowering of the safe limit (currently at $80 \mathrm{mg} / 100 \mathrm{ml}$ blood as in Britain) has proved politically acceptable.

In response to public concern over alcohol problems and after a 1974 Royal Commission of Inquiry into the Sale of Liquor in New Zealand, the Government in 1976 set up the Alcoholic Liquor Advisory Council. It has a remit "to encourage and promote moderation in the use of liquor, to discourage and reduce its misuse, and to minimise the personal, social, and economic evils resulting from the misuse of alcohol." It is financed by a levy on all alcohol sold in New Zealand and has an annual budget of just over $\$ 2 \mathrm{~m}$. The money is spent unequally on its four main tasks ${ }^{11}$ : in $1981-2$ some $44 \%$ is devoted to treatment; $29 \%$ to information and education; $15 \%$ to research; and 3\% to industry programmes. The plan is, however, to spend only $36 \%$ of the $1985-6$ budget on treatment and to increase expenditure on information and education to $38 \%$. ALAC is authorised to make recommendations to the Government and to other authorities, and to its credit one of its aims is to limit the consumption of alcohol per head. It proposes to do this primarily "by persuasion and by advocating restraint." 11

Many New Zealanders think that ALAC is hamstrung by two things: firstly, that, being a Government body (responsible to the Ministry of Justice), it has to be circumspect in what it says and so conducts rather effete campaigns; and, secondly, many see it as being too closely associated with liquor interests as it has on its council the chairman of the New Zealand Liquor Industry Council as a Government appointee. This is probably a mistake as the sad truth is that, although alcohol producers are interested in reducing damage, ultimately the interests of those genuinely concerned to reduce alcohol problems and those of alcohol producers must be directly contrary: bigger profits cannot be made from reduced consumption.

Thus ALAC, a body which at first sight seems admirable, may ultimately hinder the battle to reduce alcohol problems. This is because that battle must be political, and yet ALAC is restricted in what it can do politically. There is a lesson here, I believe, for Britain and other countries where political campaigns to reduce alcohol damage are just beginning. 


\section{References}

1 Casswell S. Alcoholism, smoking, and drug abuse. In: Richards JE, ed. Primary health care and the community. Auckland: Longman Paul, 1981.

2 Smythe M. WHO proiect on prevention of alcohol-related problems. Profiles of policies and programmes for the prevention of alcohol-related problems. New Zealand. Auckland: Alcohol Research Unit, 1981.

3 Hay DR. Cigarette smoking in New Zealand: results from the 1976 population census. $N Z$ Med $\mathcal{f} 1978 ; 88: 35-8$.

- Hay DR. Cigarette smoking. 1981 New Zealand population census. NZ Med $₹ 1982 ; 95: 52-3$.

5 Office of Population Censuses and Surveys, Social Survey Division. The general household survey, 1976. London: HMSO, 1978.
- Christmas BW, Hay DR. The smoking habits of New Zealand doctors: a review after 10 years. $N Z$ Med $71976 ; 83: 391-4$

${ }^{7}$ Beaglehole R, Hay DR, Foster FH, Sharpe DN. Trends in coronary heart disease mortality and associated risk factors in New Zealand. NZ Med f $1981 ; 93: 371-5$.

${ }^{8}$ Morrison A. "No-win" situation in New Zealand over alcohol. Otago Daily Times $1981 ; 21$ October.

- Stockwell W, Rajasingham L, eds. Employee alcohol impairment. Wellington: Accident Compensation Corporation and Alcoholic Liquor Advisory Council, 1981.

10 Smith $\mathrm{R}$. The relation between consumption and damage. $\mathrm{Br} \mathrm{Med} \mathcal{F} 1981$; $283: 895-8$.

11 Alcoholic Liquor Advisory Council. Report for the year ended 31 March 1981. Wellington: ALAC, 1981.

\section{MATERIA NON MEDICA}

\section{The train from Beijing to Guangzhou}

We have already travelled over 8000 miles by rail from Oxford Station, three of us and two small children, and the two-day journey of $2313 \mathrm{~km}$ from Beijing (old spelling Peking) to Guangzhou (old spelling Canton) is our last lap. Tomorrow morning we will be in Hong Kong, with all the riches of capitalist society at our fingertips, but tonight we are rattling south through the wide plains of central China.

In this country of a billion people the population is still reeling from the disastrous effects of the cultural revolution-"ten lost years" is the phrase we often hear repeated-when nothing and no one worked effectively, when any person or institution with the remotest bourgeois connotation was suspect. All the universities in China closed down entirely for three years, there were virtually no medical graduates for 10 years, and those who did qualify had only three years' training so now have to return to medical school as they are totally inadequate doctors. The result today: professors and senior medical staff, who during the cultural revolution were sent to the countryside as medical orderlies or, at best, itinerant village physicians, now work 12 hours and more a day well into their 70 s. Retirement is no longer a possibility: one 73-year-old professor of dermatology we met (who had been sent to wash the walls and scrub the floors of his department during those lost years) showed no more sign of slowing up than the spry 81-year-old head of Peking's Tropical Medicine Research Institute.

The couplings shriek, the train roars on through the night behind one and sometimes two powerful diesel-electric locomotives. Jerking and lurching, the effect is at its most dramatic in the dining-car. Here torrents of hot noodle-soup slop forcibly from the huge bowls on to the plastic table-covering, rapidly forming steaming rivulets which rush to the table's edge, and thence, via our laps, to the floor

The noise is at a thundering crescendo in the lavatories, which offer a choice between a draughty hole in the floor at one end of our "soft-class" carriage, and a seat at the other, but in both the floor is awash with unidentified liquid, and in neither do the taps of the handbasin or the flush work-our carriage ran out of water barely half-way to our destination. In the centre of the floor an enormous drain-hole is missing its plug; through it one shiny flanged wheel, dangerously close, is clearly visible, whizzing over the polished rail. The wind billows up from the track, together with the incessant rattle of the bogies, the squeal of brakes, and the drumming of wheels over the joins in the rails. It is quite a different pattern to the "huddledy-dee, huddledy-da" of an English branch line (no welded rail here either); more of an insistent "tic-tic-tock-tock," a cheap watch hideously speeded up and amplified.

Gripping the window-rail in the swaying corridor is the first secretary of the Indian Embassy in Peking, returning home to the Punjab with his wife after a four-year posting. Beside ourselves, they are the only non-Chinese on this train; he tells me of SinoSoviet coolness and Indo-Soviet warmth, and together we deplore Reagan's apparent hardening attitudes and deteriorating East-West détente.

Meanwhile, beyond the glass, the ochre and pale green landscape unfolds, countless fields carefully and industriously tilled, not a square foot of land unused. An ancient land is once more rebuilding.JOHN LOURIE, Professor of Human Biology, Port Moresby, Papua New Guinea.

\section{Mozart and fish}

When I was a young man my taste in music and also for food reflected the inexperience (and dogmatism) of youth. Beethoven and Brahms were my heroes of the concert hall, and a juicy steak washed down with a good heavy burgundy satisfied the inner man. Mozart, I tended to dismiss, God help me, as being rather pallid stuff, boring and repetitive. True enough, Eine Kleine Nachtmusik was quite a jolly tune, and I liked the fupiter provided it was flanked in performance by a Beethoven piano concerto or symphony. Fish I could not abide. Tasteless, bland uninteresting stuff, fit for a gastric three diet, and certainly not the sort of food that one would go out of one's way to order when eating out.

As the years have gone by, I have come to regard that youthful self, so sure and opinionated, with feelings of something like real horror and repugnance. Was it really I who voiced these prejudiced and ignorant opinions? Alas, it was so, and now within hailing distance of retirement I should like to set the record straight and make restitution.

The more one listens to music, the greater Mozart's stature becomes. His infinite variety, marvellous invention, and subtlety never fail to enthral, bringing joy and sometimes tears to the listener. The darkness and despair of the $\mathrm{D}$ minor piano concerto reflect a profundity of emotion seldom equalled, and never surpassed even by Beethoven, while the sheer exuberance and joie de vivre of Mozart's wind concertos have no peers.

And so it is with fish; not just the obvious and rather trite lobster, so beloved by schoolgirls eating out on a half-term treat, but the wonderfully subtle sole, the majestic turbot, and that richest of fish, halibut. Is it not miraculous that to go with these delicacies of the deep a benevolent providence has ordained some of the most magnificent white wines ? Montrachet, Pouilly Fuisse, and Sancerre trip off the tongue, but who could spurn a nicely chilled Chablis to accompany one's sole véronique?

The perceptive reader will have realised that this effusion is a paean of praise to maturity of taste, written by one who, standing on the hill, sees little beyond the long road declining towards its inevitable terminus at the cemetery gates. The Elgar cello concerto, surely his masterpiece, was almost his last major composition. Likewise, the Rachmaninov Variations on a Theme of Paganini, which was written and performed in 1934, almost at the end of his life, is perhaps his most unflawed work.

In youth is pleasure, but in maturity comes contemplation and contentment if one is lucky. Perhaps we should turn our backs on the philosophy that embraces "sans everything," and instead turn to the practice of warming our hands before the fire of life. Let us sup our fish and listen to Mozart the while. The lights may well be going out, but before they do, put the flute and harp concerto on the hi fi, and pass the Pouilly.-B H BASs, professor of medicine, Sutton Coldfield. 